\title{
Sports in Threat due to COVID 19 in India
}

\author{
Prof. Rajesh Kumar
}

Principal and Head, University College of Physical Education, Osmania University, Hyderabad, India

DOI: $10.36348 /$ jaspe.2020.v03i07.002

| Received: 09.07.2020 | Accepted: 18.07.2020 | Published: 21.07.2020

*Corresponding author: Prof. Rajesh Kumar

Abstract

Sports is a major contributor for economic and social development of country. The contribution of sports to empower the Youth, childrens, individuals communities to promote health and fitness. The Study is conducted through Questionnaire with google form for the Impact of Sports due to COVID 19 in India. 510 Respondents from India from all states and 62 respondents from Philippines, Malaysia, Ethiopia, Thailand and Nigeria etc. are participated in the study. Sports in Threat due to COVID 19. Many Sports Persons has lots of opportunities. Sports in dangerous situation. COVID 19 effected National Tournaments, International Tournaments, Sports Centres, Coaching Closed, monetary benefits of sports persons, coaches and sports organizations, Technical training, Physical Training, Tactical Training, Famous Sport of India IPL Cricket Postponed etc. Online Sports Coaching is not so effective for improvement of performance. Physical Exercises has become an important part to improve the immunity to have less impact of COVID 19. Social distancing cannot be done in all contact sports such as wrestling, boxing, taekwondo, Judo etc. Sports in threat globally.

Keywords: COVID 19, Sports, Coaching Closed National Tournaments, International Tournaments, Physical training, tactical training etc.

Copyright @ 2020: This is an open-access article distributed under the terms of the Creative Commons Attribution license which permits unrestricted use, distribution, and reproduction in any medium for non-commercial use (NonCommercial, or CC-BY-NC) provided the original author and source are credited.

\section{INTRODUCTION}

Sports are a major contributor for economic and social development of country. The contribution of sports to empower the Youth, childrens, individuals communities to promote health and fitness. Social distancing have also disrupted many regular aspects of life such as schools, colleges, business including sport and physical activity.

Although COVID-19 is a highly contagious disease which spreads fast and can infect any one of us, we can protect ourselves through social distancing, washing our hands regularly and following sneezing/coughing etiquettes. Despite all precautions, if anybody catches the infection, it is not their fault. In situation of distress, the patient and the family need support and cooperation. It must be noted that the condition is curable and most people recover from it. Healthcare workers including doctors, nurses, and allied $\&$ healthcare professionals are rendering their services tirelessly to provide care and medical/clinical support in this situation of crisis. Sanitary workers and police are also doing selfless service and playing critical roles in addressing the challenge of COVID-19. They all deserve our support, praise and appreciation.
Rajashekar M. Hiremath [1], studied the Role of print and electronic media during pandemic coronavirus disease 19. Print and electronic media will have a positive and negative impact. The positive impact is to take the health measures, physical distancing, use of face mask, and information regarding the use of physical exercises, yoga, meditation, immunity diet, etc. Negative impact by seeing television and reading news the community people sometimes will become anxious, depression, emotional problems, etc. Hence, role of print and electronic media during pandemic COVID-19 play a major role in regulating the disease and post-COVID scenario also [2, 3].

\section{METHODOLOGY}

The Study is conducted for the Impact of Sports due to Covid 19 in India.510 through Questionnaire from Google form through online. 510 Respondents from India from all states of the country and 62 respondents from Philippines, Malaysia, Ethiopia, Thailand, Nigeria etc are participated in the study. 


\section{RESULTS AND DISCUSSION}

The global outbreak of Covid -19 has resulted closure of sports academies, sports stadiums, Grounds, Gymnasium, Swimming Pools and fitness centre. Many Sports Persons, Sports Coaches, Sports Clubs has lost the revenue. Sports in dangerous situation and Effected in India due to Covid -19:

As Per my studies the following Sports Activities are affected.

\section{National Tournaments}

The $69.8 \%$ National Tournaments are Postponed and $30.2 \%$ are cancelled. There is no Chance to the Sports persons to exhibit the competition performance due to cancellation and Postponed of the Tournaments. The Performance will come down. All the National Tournaments are difficult to organize during the year 2020 due to pandemic.

\section{International Tournaments}

As per the study $68.8 \%$ International tournaments are postponed and $31.2 \%$ are cancelled. There is no Chance to the Elite Sports persons to exhibit the competition performance due to cancellation and Postponed of the Tournaments. The Performance will come down. The Olympic Games were due to take place in Tokyo at the end of July 2020 but, on March 24, the International Olympic Committee (IOC) took the decision to delay the Games until 2021. Given the commitment and training involved in the lead up to an Olympic year, this postponement has had a significant impact on the 11,000 Olympic athletes and 4,400 Paralympic athletes who were due to compete in the event. Many Professional Leagues are cancelled during the year 2020 .

\section{Sports Centres}

As Per the study the 87.1 Percent sport centres such as stadiums, gymnastiums, swimming pools, fitness are Closed 12.9 are Open in remote areas which is not effected by Covid. The Sports Centres in Urban areas are closed and it is open in Rural areas where no boundaries and stadium.

\section{Coaching Closed}

As per the study the $56.4 \%$ coaching is closed for Sports Persons and $43.6 \%$ are open online the online coaching is not so effective. Hence the Performance of Sports Persons will come down.

\section{Monetary Benefits: Scholarship}

As per the study the Scholarship received by Sports persons $36.8 \%$ are Postponed, $11.4 \%$ Cancelled, $51.8 \%$ are not having. There is monetary loss due to Covid for sports Persons.

\section{Frequency of Sports Training}

As per the study the frequency of training 47.4 $\%$ online and at home 6 days a week + rest, $30.1 \%$ daily and $22.4 \%$ alternate days. The frequency of Sports training also effected.

\section{Technical Training}

As per the study the Technical training which is very much important $74 \%$ are affected, $16.8 \%$ are not affected, 9.3 do not know. The Technical training in all sports and games are affected because of no practice in team and individual games all over the country.

\section{Physical fitness training}

As per the study the Physical training training which is very much important $76.7 \%$ effected, $19.7 \%$ not effected. Physical training Plays important role in the performance of sports persons which is effected due to this the performance of all sports persons will come down.

\section{Tactical Training}

As per the study the Tactical training which is very much important $75.2 \%$ are affected, $14.9 \%$ not effected, $9.8 \%$ do not know. The tactical training in all sports and games are affected because of no practice in team and individual games all over the country.

\section{Famous Sports of India -Cricket, Badminton, Athletics etc}

As per the study all the famous sports of India such as Cricket, Kabaddi, Badminton, Athletics are 81.9 Percent effected, $9.6 \%$ not effected, $8.5 \%$ do not know. IPL Cricket Matches are Postponed, Badminton Tournaments, Pro Kabaddi League, Athletics Meets, National Tournaments all are postponed and some are cancelled. There is less chance to conduct the sports at National Level due to Covid.

\section{Revenue to sports persons}

The Revenue to sports persons through Cash Awards and other sources are 76.8 \% Effected, 10.2\% not affected, $13.1 \%$ do not know. Many Professional Leagues across the globe and India has postponed or cancelled.

\section{Sporting events of India and international 2020}

$79.6 \%$ of India and International events for the year 2020 are effected. All the Tournaments are effected due pandemic.

\section{On line sports coaching}

The online sports coaching which are doing by many sports academies are $22.2 \%$ excellence, $40.8 \%$ good, $37.8 \%$ average. It is not effective source for the development of Sports Performance.

\section{Physical Exercises for Covid}

The regular Physical exercises are proven helpful especially in times of anxiety, crisis and fear. Physical Exercises are $83 \%$ good for health to improve the immune system and Physical health. 


\section{Social distancing}

Social distancing cannot be done Boxing, Wrestling, Judo, Taekwondo, Kick Boxing, Karate, Kabbadi which are the Physical contact sports will get Performance lost and cannot play for many days.

\section{CONCLUSIONS}

The sports and Games in threat because of No Practice, Stadiums Closed, Tournaments Cancelled, Tournaments Postponed, and Scholarships are cancelled and Postponed, Revenue through Cash Awards affected, Technical Training, Tactical Training, Physical training is affected. Social Distancing is difficult in physical contact sports.

Sports in threat due to covid-19 all sports persons lost opportunities to do practice and participate in the events and to get revenue from sports. Many Coaches is lost their livelihood. Many sports clubs, gymnasiums are permanently closed. All the Sports federation has stopped their activities temporarily.

\section{RECOMMENDATIONS}

The WHO Recommends 150 Minutes of Moderate intensity of 75 minutes of Vigorous intensity Physical activity per week is helpful during the Covid.

Exercise at home without any equipment and limited space can be still possible. Free online coaching from social media like Yoga, Meditation, dances etc which is helpful for whole family during the covid period.

\section{REFERENCES}

1. Rajashekar., Hiremath, M. (2020). Role of print and electronic media during pandemic coronavirus disease 19, International Journal of Health, Physical Education and Computer Science in Sports, 38(1): 155-157

2. https://www.un.org/development/desa/dspd/2020/0 5/covid-19-sport/

3. https://www.statista.com/topics/6098/impact-ofthe-coronavirus-on-sport/\#dossier. 